\title{
SELF-COMPACTING CONCRETE WITH CEM II/A-S 52,5N AND HIGH FLY ASH ADDITION IN PRECAST ELEMENTS PRODUCTION
}

\author{
Maciej Batog ${ }^{1}$, Tomasz Pużak ${ }^{2}$, Dziuk Damian ${ }^{3}$ \\ ${ }^{1}$ Centrum Technologiczne Betotech Sp. z o.o., ul. Roździeńskiego 14, 41-306 Dąbrowa Górnicza Silesian University of \\ Technology, Faculty of Civil Engineering, ul. Akademicka 5, 44-100 Gliwice, Poland \\ ${ }^{2}$ P.V. Prefabet Kluczbork S.A., ul. Kościuszki 33, 46-200 Kluczbork, Poland \\ ${ }^{3}$ Centrum Technologiczne Betotech Sp. z o.o., ul. Roździeńskiego 14, 41-306 Dąbrowa Górnicza, Poland
}

\begin{abstract}
Cements with ground granulated blast furnace slag (GGBFS) addition (CEM II and CEM III) are commonly used in concrete industry, although usually their application in precast concrete was limited due to their lower early strength comparing to Portland cement CEM I. However, on the market cements with GGBFS with high early strength are available. Portland-slag cement CEM II/A-S 52,5 N is such an example, which seems to be suitable for precast applications. In this paper results of research works and industrial experiences with self-compacting concrete containing CEM II/A-S 52,5N are presented. They confirm usefulness of cement CEM II/A-S 52,5N in mentioned application field, also with high fly ash addition.
\end{abstract}

Keywords: slag, fly ash, precast concrete, self-compacting concrete

\section{INTRODUCTION}

Portland cement CEM I in strength classes 42,5R, 52,5N and $52,5 \mathrm{R}$ are traditional cements used in small and large precast element production. Application of them allows to achieve high early strength of concrete, without using high energy consuming processes during production of precast elements (e.g. heat treatment). It is important from the technical and economical point of view (quicker turnaround of moulds and higher efficiency of precast plant). However not only strength parameters matters, but durability of precast elements is even more important. From this point of view, the most beneficial would be application of slag cement CEM III, however usage of such cements is related to slower early strength development of concrete [1] or the necessity for heat treatment in order to obtain high early strength. Cement that combines properties of both: Portland cement CEM I (high early strength) as well as slag cements CEM III (higher durability) is a Portland-slag cement CEM II/A-S 52,5 N. This paper presents the results of laboratory and industrial tests of self-compacting concrete (SCC) made from CEM II/A-S 52,5N used in the production of concrete cover plates. The use of cement CEM II/A-S 52,5N enabled us to obtain concrete with very high early and ultimate strengths, and of adequate durability.

\subsection{Requirements Regarding Element}

Cover plates are prefabricated elements made of reinforced concrete covering the wells, on which the manhole cover rests. Cover plates are joined with manhole rings by means of rubber gasket. Cover plates are reinforced in accordance with the manufacturer's design documentation [2,3]. These elements should meet the requirements of standard PN-EN 1917:2004 " Concrete manholes and inspection chambers, unreinforced, steel fibre and reinforced " [4]. Figure 1 and Table 1 show the cover plate with diameter $1200 \mathrm{~mm}$ [3].
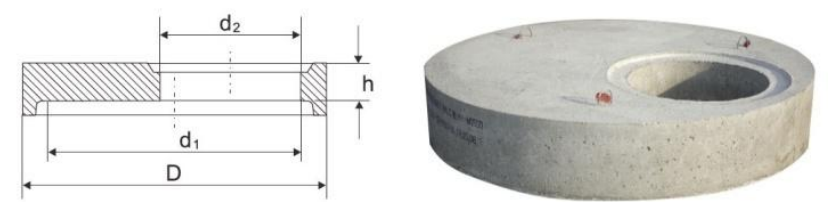

Fig. 1: Cover plate $1200 \mathrm{~mm}$ - view and dimensions

Table 1 Cover plate $1200 \mathrm{~mm}$ - the design data

\begin{tabular}{|l|l|l|l|}
\hline \multicolumn{4}{|l|}{ Cover plate, dimensions [mm] } \\
\hline $\begin{array}{l}\text { Internal } \\
\text { diameter } \\
\left(\mathrm{d}_{1}\right)\end{array}$ & $\begin{array}{l}\text { Outside } \\
\text { diameter } \\
\left(\mathrm{d}_{2}\right)\end{array}$ & $\begin{array}{l}\text { Height } \\
(\mathrm{h})\end{array}$ & $\begin{array}{l}\text { Diameter } \\
(\mathrm{D})\end{array}$ \\
\hline 1200 & 625 & 130 & 1440 \\
\hline
\end{tabular}

\subsection{Objectives of the Project}

In this study, attention was focused on the development of two concrete mix designs using Portland-slag cement CEM II/A-S $52,5 \mathrm{~N}$ for the application in the precast cover plates production. The design requirements related to the concrete mix and hardened concrete are shown in Table 2.

The aim of the study was to obtain concrete mixes with slump-flow value of $60-65 \mathrm{~cm}$, properly self - deaerating and not showing segregation of the components and the effect of water excess (bleeding). However the strength of concrete should correspond to the class C40/50 and the early strength (1 day) should be above $20 \mathrm{MPa}$. In addition, the requirements for the concrete were: degree of water permeability W8 (acc. PN-88/B-06250 [9]), the degree of freeze - thaw resistance F150 (acc. PN-88/B-06250 [9]), etc. 
Table 2 The design requirements for C40/50 SCC concrete

\begin{tabular}{|l|l|}
\hline $\begin{array}{l}\text { Requirements for concrete } \\
\text { mix }\end{array}$ & $\begin{array}{l}\text { Requirements for } \\
\text { hardened concrete }\end{array}$ \\
\hline $\begin{array}{l}\text { The consistency of concrete } \\
\text { mix: 60-65 cm as measured } \\
\text { by slump-flow test [14] }\end{array}$ & $\begin{array}{l}\text { Concrete compressive } \\
\text { strength after 1 day of } \\
\text { curing - minimum 20 MPa }\end{array}$ \\
\hline $\begin{array}{l}\text { No segregation of } \\
\text { components }\end{array}$ & Concrete class C40/50 \\
\hline $\begin{array}{l}\text { Maintaining consistency for } \\
\text { min. 30 minutes }\end{array}$ & $\begin{array}{l}\text { The degree of water } \\
\text { permeability W8[5] }\end{array}$ \\
\hline \multirow{2}{*}{$\begin{array}{l}\text { Proper deaeration of the } \\
\text { concrete mix }\end{array}$} & $\begin{array}{l}\text { Depth of water penetration } \\
\text { - maximum of 50 mm }\end{array}$ \\
\cline { 2 - 2 } & $\begin{array}{l}\text { Water absorption - no } \\
\text { more than 5\% }\end{array}$ \\
\hline \multirow{2}{*}{ No bleeding } & $\begin{array}{l}\text { The degree of freeze - } \\
\text { thaw resistance F150[5] }\end{array}$ \\
\hline
\end{tabular}

\section{PROPERTIES OF MATERIALS USED IN}

\section{TESTING}

\subsection{Cement}

Taking into account the need to provide adequate early strength that will allow fast demoulding of forms and rapid transport of finished products to the end customer, it was decided to use Portland-slag cement CEM II/A-S 52,5N.

Table 3 shows the properties of cement CEM II/A-S 52,5N as compared to the cement CEM I 42,5R, which is used widely in the production of small and large - sized precast elements, pre-stressed elements, the construction of roads, bridges, high performance concrete (HPC) and self compacting concretes SCC.

It is noteworthy that the cement CEM II/A-S 52,5N has the same high early strength ( 2 days) as cement CEM I 42,5 R and achieved higher ultimate strength. Also the heat of hydration of cement CEM II/A-S $52,5 \mathrm{~N}$ is the same as cement CEM I 42,5 $\mathrm{R}$ as shown in Figure 2. Addition of granulated blast furnace slag also positively influence the durability of concrete prepared using cement CEM II/A-S $52,5 \mathrm{~N}[1]$.

Table 3 Properties of cement

\begin{tabular}{|l|l|l|}
\hline Property & $\begin{array}{l}\text { Ordinary } \\
\text { Portland } \\
\text { Cement CEM } \\
\text { I 42,5R }\end{array}$ & $\begin{array}{l}\text { Portland-slag } \\
\text { cement CEM } \\
\text { II/A-S 52,5N }\end{array}$ \\
\hline $\begin{array}{l}\text { Soundness, Le } \\
\text { Chatelier }\end{array}$ & $0,3 \mathrm{~mm}$ & $0,4 \mathrm{~mm}$ \\
\hline Initial setting time & 183 minutes & 161 minutes \\
\hline $\begin{array}{l}\text { Compressive strength } \\
\text { after 2 days }\end{array}$ & $29,3 \mathrm{MPa}$ & $28,9 \mathrm{MPa}$ \\
\hline $\begin{array}{l}\text { Compressive strength } \\
\text { after 28 days }\end{array}$ & $59,2 \mathrm{MPa}$ & $63,1 \mathrm{MPa}$ \\
\hline
\end{tabular}

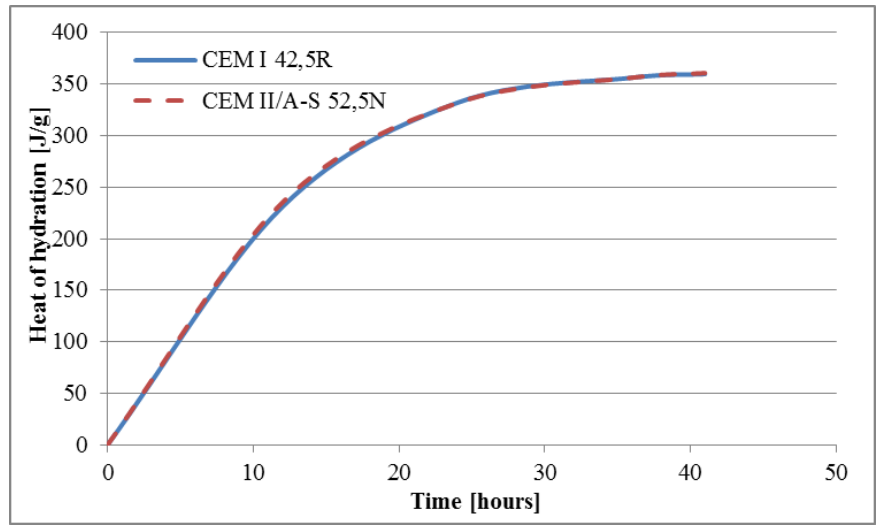

Fig 2: Heat of hydration of cement

\subsection{Aggregates}

To design the composition of the concrete mix local gravel was used and designed grading curve is shown in Figure 3. Particular attention was paid to the grain size of sand. Applied aggregate allowed to achieve the proper slump-flow of the concrete and the proper filling the space in the prepared element (densely arranged reinforcement).

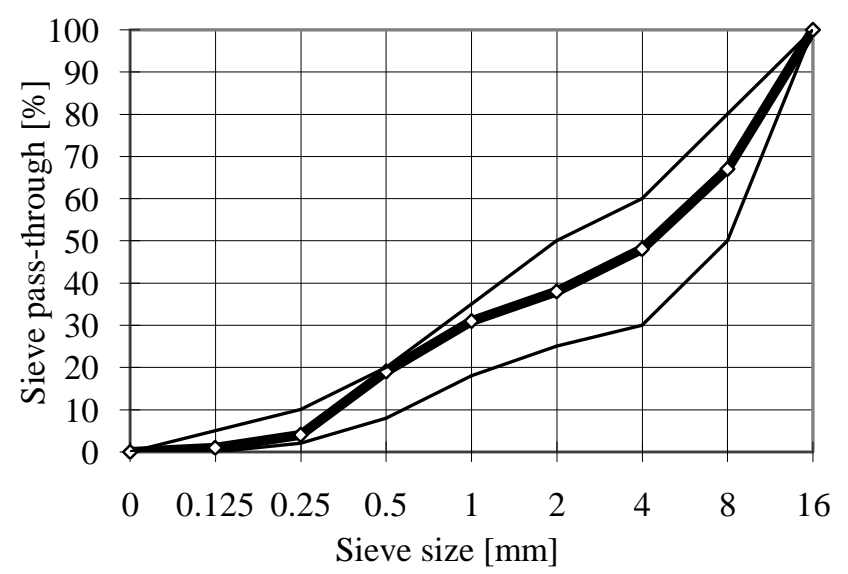

Fig 3 Aggregate grading curve

\subsection{Fly Ash}

The basis for the construction of the SCC mix is sufficiently high fine fraction in concrete (less than $0,125 \mathrm{~mm}$ ). This implies the need to use appropriate mineral fillers in SCC concrete. As a result a low value of the yield value and high viscosity of the concrete [1,5] is achieved. This role cannot be performed by cement, as this would result in too high shrinkage, yet not without significance is the economic aspect.

Carefully selected mineral admixture, together with cement, ensures proper flowability of the concrete and allows prolonged workability (processability) of concrete. In this study, high quality siliceous fly ash with the properties and the composition presented in Table 4 and 5 was used. Fly ash used meet the requirements of standard PN EN 4501:2006 "Fly ash for concrete" (category A and N) [5]. 
Table 4 Physical properties of fly ash

\begin{tabular}{|c|c|c|c|c|c|c|c|}
\hline \multirow[b]{2}{*}{$\begin{array}{l}\text { Loss } \\
\text { on } \\
\text { igniti } \\
\text { on }\end{array}$} & \multirow[b]{2}{*}{$\begin{array}{l}\mathrm{S} \\
\mathrm{O}_{3}\end{array}$} & \multirow[b]{2}{*}{$\begin{array}{l}\mathrm{CaO}_{\mathrm{f}} \\
\text { ree }\end{array}$} & \multirow[b]{2}{*}{$\mathrm{Cl}^{-}$} & \multicolumn{2}{|c|}{$\begin{array}{l}\text { Pozzolani } \\
\text { c activity }\end{array}$} & \multirow[b]{2}{*}{$\begin{array}{l}\text { Finen } \\
\text { ess }\end{array}$} & \multirow[b]{2}{*}{$\begin{array}{l}\text { Densi } \\
\text { ty }\end{array}$} \\
\hline & & & & $\begin{array}{l}\text { aft } \\
\text { er } \\
28 \\
\text { day } \\
\text { s }\end{array}$ & $\begin{array}{l}\text { aft } \\
\text { er } \\
90 \\
\text { day } \\
\text { s }\end{array}$ & & \\
\hline$[\%]$ & {$[\%$} & {$[\%]$} & {$[\%]$} & {$[\%]$} & {$[\%]$} & {$[\%]$} & {$[\mathrm{g} / \mathrm{cm}$} \\
\hline 2,24 & $\begin{array}{l}0,6 \\
7\end{array}$ & 0,07 & $\begin{array}{l}0,0 \\
07\end{array}$ & $\begin{array}{l}80, \\
0\end{array}$ & $\begin{array}{l}90, \\
8\end{array}$ & 34,0 & 2,21 \\
\hline
\end{tabular}

Table 5 Chemical composition of fly ash

\begin{tabular}{|l|l|l|l|l|}
\hline \multicolumn{6}{|l|}{ Content [\% mass] } \\
\hline $\mathrm{SiO}_{\mathbf{2}}$ & $\mathbf{A l}_{\mathbf{2}} \mathbf{O}_{\mathbf{3}}$ & $\mathbf{F e}_{\mathbf{2}} \mathbf{O}_{\mathbf{3}}$ & $\mathbf{C a O}_{\text {free }}$ & $\mathbf{C a O}$ \\
\hline 51,50 & 27,83 & 7,50 & 0,07 & 3,68 \\
\hline $\mathbf{M g O}$ & $\mathbf{S O}_{\mathbf{3}}$ & $\mathbf{N a}_{\mathbf{2}} \mathbf{O}$ & $\mathbf{K}_{\mathbf{2}} \mathbf{O}$ & $\mathrm{Cl}^{-}$ \\
\hline 2,51 & 0,67 & 1,07 & 2,97 & 0,007 \\
\hline
\end{tabular}

\subsection{Admixtures}

In the production of nearly- and self-compacting concretes primary task of super plasticizer is to give the concrete mix with a low w/c coefficient very high liquidity ensuring selfleveling properties and the possibility of spontaneous deaeration. In designing and preparation of concrete admixture based on polycarboxylate ether was used. It is an admixture designed for production of precast elements, concretes with high initial strength and pre-stressed concrete. The use of this type of superplasticizer allows the production of concretes with a low w/c ratio, what leads to obtaining concrete with high strengths, both early and ultimate (after 28 days of curing).

Concretes made with this admixture have the ability to maintain proper consistency even at increased ambient temperatures. This type of admixture accelerates the hydration of cement phases, what results in the hardening process, especially in the initial period, that more heat is released. This results in a relatively high level of early strength of concrete.

\section{PROPERTIES OF FRESH AND HARDENED CONCRETE}

Designing the SCC concrete primarily the properties of the concrete mix should be remembered. The concrete mix should be characterized by:

- the slump-flow of at least $60 \mathrm{~cm} \mathrm{[14],} \mathrm{which} \mathrm{ensures}$ proper fluidity of the concrete that allows spontaneous spreading of the mixture in the form of a cover plate (Fig. 1),

- $\quad$ maintaining consistency for at least 30 minutes. The time required to maintain the consistency was based on the length of the technological processes taking place in the precast plant, taking into account a margin of safety. It should be noted that the use of concrete of different consistency than the estimate, causes abnormal deaeration of the mixture, which will further have an adverse effect on the properties and aesthetical aspects of produced element,

- the flow speed to a diameter of $50 \mathrm{~cm} \mathrm{-} \mathrm{5-10} \mathrm{sec.;}$ allows to maintain the proper tempo of placing the concrete.

The compositions of designed and tested concrete mixtures are shown in Table 6 and their properties in Table 7.

Table 6 Recipes of SCC concrete

\begin{tabular}{|l|l|l|}
\hline \multirow{2}{*}{ Constituent } & \multicolumn{2}{|l|}{ Amount [kg/m $\left.\mathbf{3}^{\mathbf{3}}\right]$} \\
\cline { 2 - 3 } & Recipe 1 & Recipe 2 \\
\hline Cement CEM II/A-S 52,5N & 350 & 350 \\
\hline Sand 0-2 mm & 605 & 600 \\
\hline Gravel 2-8 mm & 480 & 540 \\
\hline Gravel 8-16 mm & 560 & 440 \\
\hline Fly ash & 160 & 250 \\
\hline Water & 148 & 160 \\
\hline Superplasticizer & $1,2 \%$ m.c. & $1,6 \%$ m.c. \\
\hline w/s (w/(c+0,4p)) & 0,37 & 0,40 \\
\hline
\end{tabular}

Table 7 Properties of the concrete mixture - laboratory tests

\begin{tabular}{|c|c|c|c|}
\hline \multirow{2}{*}{\multicolumn{2}{|c|}{ Requirement }} & \multicolumn{2}{|l|}{ Results } \\
\hline & & \multirow{2}{*}{$\begin{array}{l}\text { Recipe } 1 \\
68 \mathrm{~cm}\end{array}$} & \multirow{2}{*}{\begin{tabular}{|l} 
Recipe 2 \\
$72 \mathrm{~cm}$
\end{tabular}} \\
\hline Concrete & $\begin{array}{l}\text { after } \\
\text { mixing }\end{array}$ & & \\
\hline consistency & $\begin{array}{l}\text { after } 45 \\
\text { minutes }\end{array}$ & $65 \mathrm{~cm}$ & $69 \mathrm{~cm}$ \\
\hline \multicolumn{2}{|l|}{ Flow Speed } & $8 \mathrm{sec}$ & $7 \mathrm{sec}$ \\
\hline \multicolumn{2}{|l|}{ Air content } & $2,2 \%$ & $1,8 \%$ \\
\hline \multicolumn{2}{|c|}{$\begin{array}{l}\text { Deaeration of concrete } \\
\text { mixture }\end{array}$} & correct & correct \\
\hline \multicolumn{2}{|l|}{ Bleeding } & no & no \\
\hline \multicolumn{2}{|c|}{ Segregation of constituents } & no & no \\
\hline \multicolumn{2}{|c|}{$\begin{array}{l}\text { Temperature of concrete } \\
\text { mixture }\end{array}$} & $22,3{ }^{\circ} \mathrm{C}$ & $22,6^{\circ} \mathrm{C}$ \\
\hline
\end{tabular}

After establishing compositions of concrete mixes, concrete was applied to the cubic forms with size dimension of 15 $\mathrm{cm}$, without vibration (SCC concrete). After storage of concrete samples under laboratory conditions (temperature $20^{\circ} \mathrm{C} \pm 2{ }^{\circ} \mathrm{C}$, relative humidity $95 \% \pm 5 \%$ ), they were subjected to tests to obtain the confirmation of the assumed quality parameters of the concrete and to investigate the influence of cement CEM II/A-S $52,5 \mathrm{~N}$ on the concrete compressive strength (Fig. 5). The results of the compressive strength in both cases - made by the recipe no. 1 and no. 2 confirmed assumed strength parameters. Figure 4 shows a method of measuring the consistency of concrete by slump-flow method [14]. 


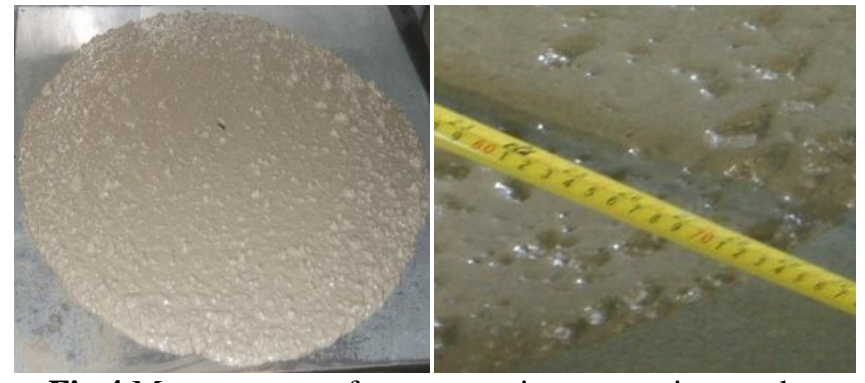

Fig 4 Measurement of concrete mixture consistency by means of slump-flow test [14](recipe 2)

When designing self-compacting concrete, special attention is placed on obtaining the properties of the concrete mix and the other parameters are usually derived from these requirements and usually significantly exceed designed values. The parameters obtained by the two concrete mixtures made it possible to conduct industrial trial. It was decided to conduct industrial trial using a mix with no. 1 recipe, due to higher early strength obtained by it.

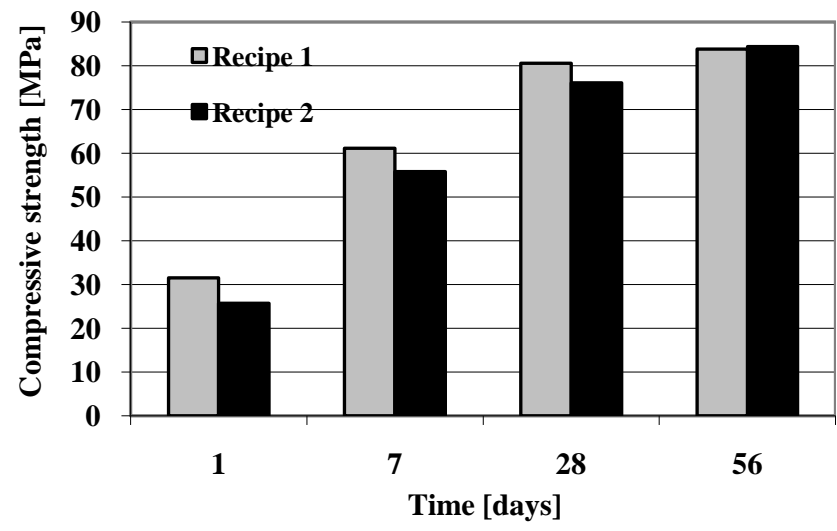

Fig 5 The compressive strength of concrete - laboratory tests

Industrial trial was held with earlier tested recipe with some minor adjustments of sand content and the mixing water. During the trial cover plate with a diameter of $1200 \mathrm{~mm}$ (Fig. 6) and a concrete ring of the same diameter were prepared. The figure shows the successive stages of placing concrete cover plate. During trial cube samples were moulded for further study. The scope of the research included:

- $\quad$ test of the compressive strength of concrete at 7, 28 and 56 days acc. to PN-EN 12390-3 [4],

- testing freeze-thaw resistance with de-icing chemicals acc. to PKN-CEN/TS 12390-9[5],

- testing freeze-thaw resistance in the water - F150 degree acc. to PN-B/88-06250[2] - compressive strength loss $\leq 20 \%$ and weight loss $\leq 5 \%$ after 150 freeze-thaw cycles,

- depth of penetration of water under pressure (PNEN 12390-8)[6],

- water permeability W8 degree acc. to PN-B/8806250[5] - no signs of water permeability through concrete sample under water pressure of $0,8 \mathrm{MPa}$ after 24 hours.
Samples prepared during technological tests were kept under laboratory conditions (temperature $20^{\circ} \mathrm{C} \pm 2{ }^{\circ} \mathrm{C}$, relative humidity $95 \% \pm 5 \%$ ). In order to check the influence of the ambient temperature in the production floor on the parameters of a concrete used to made a cover plate, cores with a diameter of $100 \mathrm{~mm}$ were cut from it (ring until sampling was kept in the production floor). The scope of research was the same as for samples collected during casting of concrete cover plate, except for the strength test, which was carried out in accordance with PN-EN 12504-1 tests of concrete in structures - Part 1: Cored specimens. Taking, examining and testing in compression [11].

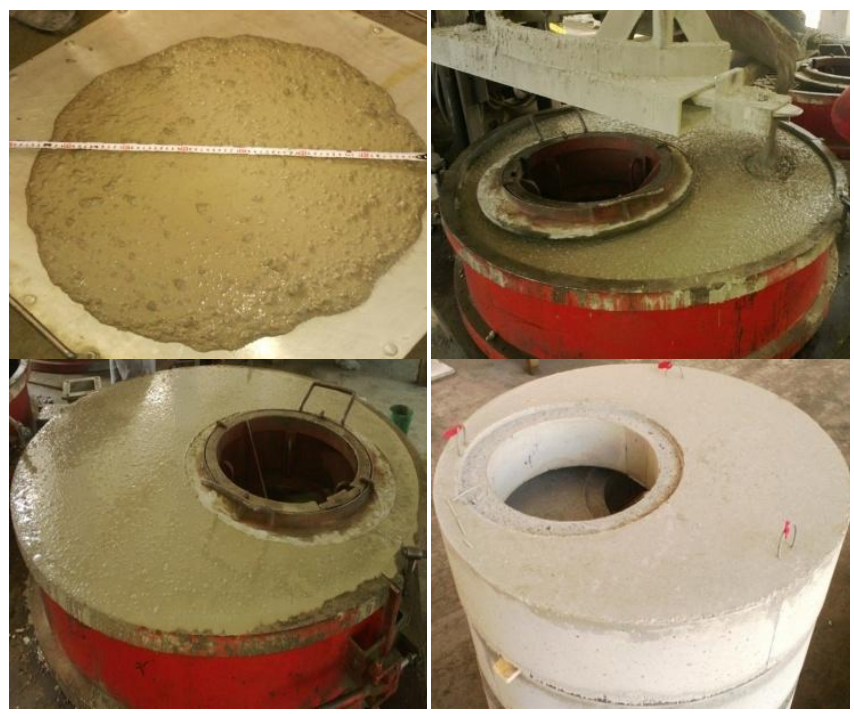

Fig 6 Industrial trial using SCC concrete made of cement CEM II/A-S 52,5N (recipe no. 1): a) testing slump-flow[14],

b) filling the cover plate mould, c) mould after complete filling with concrete, d) product after demoulding.

The results of the compressive strength of the samples taken during the industrial trial and cores taken from the finished components confirmed design assumptions (Fig. 7) and even exceeded them significantly.

The results of durability tests of concrete are presented in Table 8. Concrete produced during the industrial trial was characterized by a very good freeze-thaw resistance, what was confirmed by laboratory testing of samples and cores taken from the finished item. The decrease in compressive strength and weight loss was respectively $\leq 20 \%$ and $\leq 5 \%$ (limits acc. PN-88/B-06250).

However, the scaled material after 56 freeze-thaw cycles did not exceed $0,5 \mathrm{~kg} / \mathrm{m}^{2}$, what corresponds to the requirements for concrete paving highest class FT2 in accordance with PN-EN 13877-2 "Concrete pavements - Part 2: Functional requirements for concrete pavements" [12].

The tested concrete was also characterized by a very good impermeability meeting the requirements for the degree of water permeability W8 limits acc. PN-88/B-06250 and penetration depth of water under a pressure of $<50 \mathrm{~mm}$, what allows to qualify it in accordance with the German guidelines as impermeable concrete [13]. 


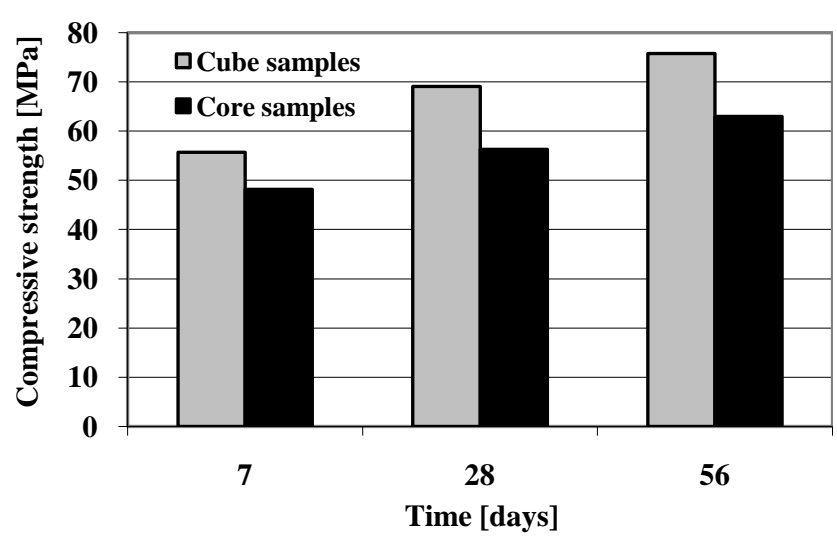

Fig 7 The compressive strength of concrete (recipe No. 1) Industrial trial

Table 8 Test results - Industrial trial

\begin{tabular}{|c|c|c|c|}
\hline \multirow{2}{*}{\multicolumn{2}{|c|}{ Property }} & \multicolumn{2}{|c|}{ CEM II/A-S 52,5N } \\
\hline & & \multirow{2}{*}{$\begin{array}{l}\begin{array}{l}\text { Cube } \\
\text { samples }\end{array} \\
66,7\end{array}$} & \multirow{2}{*}{$\begin{array}{l}\text { Core } \\
\text { samples }\end{array}$} \\
\hline$\sum_{\substack{\infty \\
\delta}}^{\pi}$ & $\begin{array}{l}\text { Samples after } 150 \\
\text { cycles of freezing- } \\
\text { thawing }\end{array}$ & & \\
\hline 苂 & Reference samples & 73,2 & 62,8 \\
\hline \multicolumn{2}{|c|}{$\begin{array}{l}\text { The decrease in strength of } \\
\text { the samples after } 150 \text { cycles } \\
\text { in relation to the strength of } \\
\text { reference samples [\%] }\end{array}$} & 8,9 & 10,9 \\
\hline \multicolumn{2}{|c|}{$\begin{array}{l}\text { The weight loss of samples } \\
\text { after } 150 \text { cycles [\%] }\end{array}$} & 0,5 & 0,9 \\
\hline \multicolumn{2}{|c|}{$\begin{array}{l}\text { Scaling after } 56 \text { freeze-thaw } \\
\text { cycles }\left[\mathrm{kg} / \mathrm{m}^{2}\right]\end{array}$} & 0,10 & 0,16 \\
\hline \multicolumn{2}{|c|}{$\begin{array}{l}\text { The depth of penetration of } \\
\text { water under pressure [mm] }\end{array}$} & 7 & 11 \\
\hline \multicolumn{2}{|c|}{$\begin{array}{l}\text { Water permeability - the } \\
\text { degree W8 }\end{array}$} & $\begin{array}{l}\text { complied } \\
\text { with the } \\
\text { requirements }\end{array}$ & $\begin{array}{l}\text { complied } \\
\text { with the } \\
\text { requirements }\end{array}$ \\
\hline
\end{tabular}

\section{CONCLUSION}

Designed concrete with cement CEM II/A-S 52,5N was characterized by high early (1, 7 days) and ultimate (28 days) strength. Concrete was also characterized by a very good durability parameters - very good freeze-thaw resistance and high impermeability. Based on the research it can be concluded that the use of cement CEM II/A-S 52,5N is technically and economically justified. Portland-slag cement CEM II/A-S $52,5 \mathrm{~N}$ is the cement that can be successfully used in the large and small-sized precast production as a replacement for Portland cement CEM I of high strength classes (42,5 R, 52,5 $\mathrm{N}$ and 52,5 R).

\section{REFERENCES}

[1]. Giergiczny Z., Małolepszy J., Szwabowski J., Śliwiński J.: „Cementy $\mathrm{z}$ dodatkami mineralnymi $\mathrm{w}$ technologii betonów nowej generacji”, Wydawnictwo Instytut Śląski Sp. z o.o. w Opolu, Opole 2002.

[2]. Madryas C., Kolonko A., Wysocki L. „Konstrukcje przewodów kanalizacyjnych", Wrocław 2002.

[3]. Promotional materials of P.V. Prefabet Kluczbork company

[4]. PN-EN 1917:2004 "Concrete manholes and inspection chambers, unreinforced, steel fibre and reinforced"

[5]. PN EN 450-1:2006 "Fly ash for concrete"

[6]. Domone P.L. „Self-compacting concrete: An analysis of 11 years of case studier" Cement \& Concrete Composites 28 (2006), pp. 197-208

[7]. PN-EN 12390-3:2011 "Testing hardened concrete. Compressive strength of test specimens"

[8]. PKN-CEN/TS 12390-9:2007 "Testing hardened concrete -- Part 9: Freeze-thaw resistance - Scaling"

[9]. PN-B-06250:1988 "Regular concrete"

[10]. PN-EN 12390-8:2011 "Testing hardened concrete Part 8: Depth of penetration of water under pressure"

[11]. PN-EN 12504-1:2011 „Testing Concrete In Structures - Part 1: Cored Specimens - Testing, Examining And Testing In Compression"

[12]. PN-EN 13877-2 "Concrete pavements - Part 1: Functional requirements for concrete pavements "

[13]. DIN 1045-2:2008 „Tragwerke aus Beton, Stahlbeton und Spannbeteton. Teil 2: Beton - Festlegung, Eigenschaften, Herstellung und Konformität. Anwendungsregeln zu DIN EN 206-1")

[14]. PN-EN 12350-8:2012 "Testing fresh concrete - Part 8: Self-compacting concrete - Slump-flow test"

\section{BIOGRAPHIES}

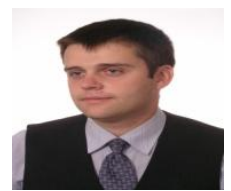

Maciej Batog, has received his master's degree from the AGH University of Science and Technology, Cracow, Poland. Currently working as R\&D Coordinator in Technological Center Betotech. His research interests are in the field of cements with low clinker content, concrete for massive structures and application of mineral additives in concrete.

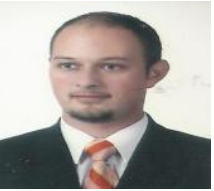

Damian Dziuk, has received the Ph.D. degree from the Silesian University of Technology, Gliwice, Poland. Currently working as Deputy Manager of Construction Materials Laboratory in Technological Center Betotech. His research interests are in the field of non-clinker components in the cement.

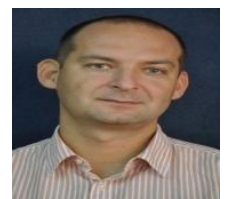

Tomasz Pużak, has received his master's degree from the Opole University of Technology, Opole, Poland. Currently working as Quality Manager in P.V. Prefabet Kluczbork S.A. His research interests are in the field of precast elements, SCC construction and durability of concrete. 